\title{
The Role of $\beta$-Adrenoreceptor Stimulation and Contractile State in the Preterm Lamb's Response to Altered Ductus Arteriosus Patency
}

\author{
RONALD I. CLYMAN, DAVID TEITEL, JAMES PADBURY, CHRISTINE ROMAN, AND \\ FRANÇOISE MAURAY \\ The Cardiovascular Research Institute, University of California, San Francisco, and the Departments of \\ Pediatrics, University of California, San Francisco, Mt. Zion Hospital and Medical Center, San Francisco, and \\ Harbor-UCLA Medical Center, Torrance, California 94143
}

\begin{abstract}
A model of patent ductus arteriosus in premature lambs was created to study the relative importance of $\beta$-adrenoreceptor stimulation and increased myocardial contractility. In 39 fetal lambs $(133 \pm 2, \pm$ SD days gestation, term 145 days), the ductus arteriosus was infiltrated with formalin, and a snare was placed around it to regulate its patency. One day later, the lambs were delivered, given sheep surfactant, paralyzed, and mechanically ventilated. Microsphere measurements of left ventricular output were made between 4 and $6 \mathrm{~h}$ after delivery. When the ductus was opened, there was no change in heart rate, but there were significant increases in left ventricular output, stroke volume, left ventricular end-diastolic pressure, and peak $\mathrm{dP} / \mathrm{dt}$. The increase in peak $\mathrm{dP} / \mathrm{dt}$ due to opening the ductus was greater than that due to an increase in left ventricular end-diastolic pressure alone and was accompanied by an increase in norepinephrine secretion from the left ventricle. Propranolol $(1 \mathrm{mg} / \mathrm{kg})$ was used to evaluate the effect of $\beta$-adrenergic tone on left ventricular output and contractility. The left atrium was paced in both control and propranolol-treated lambs. When the ductus was closed, propranolol significantly decreased stroke volume and peak $\mathrm{dP} / \mathrm{dt}$ without changing left ventricular end-diastolic pressure or systemic vascular resistance. During a saline volume load $(50 \mathrm{ml} / \mathrm{kg}$ over a 3-min period), propranolol-treated lambs had a reduced stroke volume and peak $\mathrm{dP} / \mathrm{dt}$ despite similar values of left ventricular end-diastolic pressure and resistance as those of control lambs. Therefore, $\beta$-adrenergic tone plays a significant role in increasing contractile state and left ventricular performance in preterm lambs when they are challenged with a volume load such as a patent ductus arteriosus. (Pediatr Res 23: 316-322, 1988)
\end{abstract}

\section{Abbreviations}

PDA, patent ductus arteriosus

$L V$, left ventricle

$\mathrm{dP} / \mathrm{dt}$, first derivative of $\mathrm{LV}$ pressure during systole

$\dot{Q} \mathbf{L V}$, left ventricular output

$\dot{Q}$ ductus, blood flow through the ductus arteriosus

Q pulmonary, pulmonary blood flow

Q systemic, systemic blood flow

$\mathbf{R}$ pulmonary, pulmonary vascular resistance

$\mathbf{R}$ systemic, systemic vascular resistance

$R$ total, total resistance for the $\mathbf{L V}$

Received August 31, 1987; accepted November 16, 1987.

Correspondence Ronald I. Clyman, M.D., Box 0544, Room 1403 HSE, University of California, San Francisco, San Francisco, CA 94143.

Supported by grants from the United States Public Health Service, SCOR HL27356; Program Project Grant HL-24056, and HD-18014.

\author{
A, aorta \\ $\mathrm{V}$, coronary sinus \\ NE, norepinephrine \\ E, epinephrine \\ $\mathbf{R}_{\mathrm{T}}$, afterload
}

LVEDP, left ventricular end diastolic blood pressure

The PDA is believed to represent a significant stress for the premature cardiovascular system. The pathologic features of a PDA depend both on the magnitude of the left to right shunt through the ductus and on the cardiovascular responses to the shunt. Adult animals compensate for a large arteriovenous fistula by increases in preload through increased venous return and by decreases in afterload, as well as by increases in catecholamine secretion, heart rate, and contractility (1-3). We previously have found that premature lambs are able to double their left ventricular output in response to a PDA (4). This is due primarily to an increase in preload and a decrease in afterload (5). The role of myocardial contractility in this response has not been examined. Studies in full-term neonatal lambs have suggested that the newborn has a limited ability to increase its myocardial contractility. Sympathetic innervation of the newborn heart is incomplete at term, and the immature myocardium appears to be more dependent on, and more sensitive to, circulating catecholamines (6). Catecholamine concentrations rise abruptly to very high levels at birth $(7,8)$, and this increase is associated with marked increases in cardiac output and oxygen consumption (9-14). Thus the newborn myocardium may be unable to increase its contractility in response to increased demand [e.g. volume loading or $\beta$-adrenergic stimulation (11-14)] when it is already functioning under a high level of adrenergic stimulation. We have created a premature lamb model of PDA to examine the role of $\beta$-adrenoreceptor stimulation and increased myocardial contractility in the heart's ability to increase its cardiac output when challenged with a volume load. The role of changes in preload and afterload has been considered previously (5).

\section{METHODS}

Preparation. Thirty-nine mixed Western breed time-dated pregnant ewes at 129 to 134 days gestation (133 $\pm 2, \pm \mathrm{SD}$ days, term 145 days) were fasted, but allowed free access to water, for 24-48 h before surgery. Surgery was performed under epidural anesthesia with $2-4 \mathrm{ml}$ of $1 \%$ tetracaine hydrochloride. Ketamine $(100 \mathrm{mg}$ ) was administered intravenously every $15-30 \mathrm{~min}$ for sedation. Local anesthesia with $0.25 \%$ lidocaine hydrochloride 
was used for all fetal incisions. A continuous intravenous infusion of $10 \%$ dextrose in $0.9 \% \mathrm{NaCl}$ was given to the ewe throughout the surgery.

In the ewe, polyvinyl catheters were inserted into the pedal vein and artery and advanced into the inferior vena cava and descending aorta, respectively. A hysterotomy was performed, and polyvinyl catheters also were inserted into the pedal vein and artery of the fetus and advanced into the inferior vena cava and descending aorta. A left thoracotomy was performed, and the left lung was retracted to expose the great vessels and the ductus arteriosus. The ductus was dissected from the surrounding tissue, and $10 \%$ buffered formalin was injected into the vessel wall to destroy the muscular layer. Then a mechanical snare (made from a cardiac catheterization guide wire and catheter sheath) was looped around the ductus and brought through the fetal chest wall. Catheters were placed in the pulmonary artery and internal mammary artery and vein. A pair of stainless steel pacing wires were sutured to the left atrial epicardium. In seven fetuses, a catheter was placed in the coronary sinus via the left hemiazygous vein (15). Catheters and wires were tunneled subcutaneously to the ewe's flank and secured there in a pouch. The thoractotomy and hysterotomy were closed, and the pregnancy allowed to continue.

After 1 day for surgical recovery, the abdominal incision in the ewe was reopened under epidural anesthesia, and the fetus was delivered onto the maternal abdomen. The fetus was paralyzed with pancuronium bromide $(0.4 \mathrm{mg}$ intravenously). The trachea was intubated with a $4.5 \mathrm{~F}$ cuffed endotracheal tube, and sheep surfactant was instilled into the trachea $(50 \mathrm{mg}$ surfacant lipid $/ \mathrm{kg}$ body weight). The sheep surfactant was prepared from lung lavages of healthy adult sheep as described previously (16). As the surfactant was instilled, the fetus was positioned from side to side to achieve even lung distribution. Then the umbilical cord was ligated, and the lamb was delivered to a warming table and ventilated (in the prone position) with an infant ventilator (Sechrist, Anaheim, CA). Through umbilical and perhipheral vessel cutdowns (using local anesthesia), additional intravascular catheters were passed into the newborn lamb's LV, right atrium, and umbilical artery. In addition, a $5 \mathrm{~F}$ transducer-tipped catheter (Gaeltec Ltd., Medical Measurements Inc., Hackensack, NJ) was placed in the right carotid artery and advanced into the left ventricle. All catheters were placed and secured by 30 min after delivery. All intravascular catheters were kept patent by small, intermittent boluses of $5 \%$ dextrose in warm $(<2-3 \mathrm{ml} / \mathrm{kg} / \mathrm{h})$.

The initial ventilator settings were: peak inspiratory pressure, $28 \mathrm{~cm}$ water; positive-end-expiratory pressure, $3 \mathrm{~cm}$ water; inspiratory time, $0.6 \mathrm{~s}$; and respiratory rate, $60 \mathrm{breaths} / \mathrm{min}$. The initial $\mathrm{FiO}_{2}$ was $100 \%$. After 30 min stabilization, the ventilator rate was decreased (by increasing the expiratory time) to $30-40$ breaths/min. The $\mathrm{PaO}_{2}$ was maintained between 150 and 300 torr by adjusting the $\mathrm{FiO}_{2}$; the $\mathrm{PaCO}_{2}$ was maintained between 25 and 40 torr by adjusting the peak inspiratory pressure. This range of values was chosen to reduce pulmonary vascular resistance so that any left to right shunt through the ductus arteriosus would be maximized. An intravenous infusion of $5 \%$ dextrose in water at a rate of $5 \mathrm{ml} / \mathrm{kg} / \mathrm{h}$ was begun after delivery. The lambs initially were towel-dried and covered with a plastic sheet to reduce evaporative losses. Rectal temperature was maintained between 38 and $39^{\circ} \mathrm{C}$ with Aquamatic K-pads and with radiant heat lamps. Pancuronium bromide was administered as needed to maintain paralysis. For sedation, diazepam (Valium IV, Hoffmann LaRoche, Nutley, NJ), $0.1 \mathrm{mg} / \mathrm{kg}$ intravenously, was given shortly after delivery. Heparinized maternal blood was transfused to replace blood lost from sampling.

Cardiovascular function measurements. Vascular pressures (femoral arterial, pulmonary arterial), right atrial pressures, and left ventricular pressures were measured continuously using Beckman pressure transducers (Sensormedics, Anaheim, CA) and a Sensormedics Dynograph R611 multichannel recorder (Anaheim, CA). The signal was averaged electronically to obtain mean pressures. The transducer-tipped LV catheter was externally calibrated with a mercury manometer and was periodically matched to in vivo pressure recordings from the fluid-filled LV catheter. The rate of rise, or first derivative of LV pressure (dP/ $\mathrm{dt}$ ), and the peak rate of rise (peak $\mathrm{dP} / \mathrm{dt}$ ) were measured using a Sensormedics 9879 DP/DT coupler.

To measure blood flows, we injected approximately $10^{6}$ radiolabeled $15 \mu \mathrm{m}$ microspheres into the LV while reference blood samples were withdrawn from the ascending and descending aorta (16). After the experient, the lamb was killed with $3 \mathrm{ml}$ of Euthanasia-6 Solution (Veterinary Laboratories, Lenexa, KS), and the position of all catheters and function of the mechanical snare were verified. The organs were removed, weighed, and placed in formalin. They were incinerated at $325^{\circ} \mathrm{C}$ for $72 \mathrm{~h}$, pulverized, and packed into counting vials. The amount of each radionuclide in the organs and reference blood samples was measured with a well-type gamma scintillation counter and a multiple-channel pulse height analyzer.

$\dot{Q} \mathrm{LV}$ was calculated using the concentration of microspheres in the reference samples, and the total number of microspheres recovered from the whole animal. Left to right $\dot{Q}$ ductus was calculated using the concentration of microspheres in the reference samples and the total number of microspheres in the lungs (16); an assumed bronchial blood flow of $8 \%$ of $\dot{Q} \mathrm{LV}$ was subtracted from the measured lung blood flows. This amount was determined from measurements made in 35 newborn lambs (130-135 days) in which the ductus had been ligated (Clyman RI, unpublished observations). We previously have found, using microspheres injected into the inferior vena cava, that right to left shunting of blood through the foramen ovale was less than $4 \%$ of venous return in newborn lambs (130-135 days) 2-10 h after delivery; we have not been able to detect any right to left shunting of blood through the ductus arteriosus (Clyman RI, unpublished observations). Therefore, $\dot{Q}$ pulmonary was considered equal to the $\dot{Q} \mathrm{LV}$, and effective $\dot{Q}$ systemic was estimated as the Q LV minus the left to right ductal shunt.

Resistances to blood flow were calculated from the pressure and flow measurements. R pulmonary was calculated by dividing (the mean pulmonary arterial - left ventricular end-diastolic pressure difference) by pulmonary blood flow. Systemic vascular resistance ( $R$ systemic) was calculated by dividing (the mean aortic - right atrial pressure difference) by effective systemic blood flow. Ductus arteriosus resistance ( $\mathrm{R}$ ductus) was calculated by dividing (the mean aortic - pulmonary arterial pressure difference) by the ductus arteriosus flow. Total resistance against which the left ventricle pumps ( $R$ total) was calculated from the formula:

$$
\frac{1}{\mathrm{R} \text { total }}=\frac{1}{(\mathrm{R} \text { pulmonary }+\mathrm{R} \text { ductus })}+\frac{1}{\mathrm{R} \text { systemic }}
$$

Arterial $\mathrm{pH}, \mathrm{PaO}_{2}$, and $\mathrm{PaCO}_{2}$ were measured with a Corning 158 blood gas analyzer (Corning Medical and Scientific, Medfield, MA).

Catecholamine measurements. From the ascending $\mathrm{A}$ and $\mathrm{V}$, $2 \mathrm{ml}$ blood samples were drawn simultaneously into tubes containing reduced glutathione and EGTA for measurement of plasma catecholamines. The plasma was separated and frozen at $-30^{\circ} \mathrm{C}$ until subsequent assay (8). Plasma NE and E concentrations were determined in duplicate $50-\mu$ l aliquots of plasma using the single isotope radioenzymatic assay of Padbury et al. (8) and Passon and Peuler (17). The sensitivity of the assay is $1-2 \mathrm{pg}$ for $\mathrm{NE}$ and $\mathrm{E}$

The hematocrit was measured to convert left ventricular free wall blood flow rate to plasma flow. The plasma flow was expressed as $\mathrm{ml} / \mathrm{min} / \mathrm{g}$ of $\mathrm{LV}$ tissue to facilitate comparisons between experiments.

Fractional extraction of catecholamines and net LV uptake were calculated as follows: fractional extraction $(\%)=(A-V / A)$ $\mathrm{x} 100$, and net uptake $(\mathrm{pg} / \mathrm{min} / \mathrm{g}$ LV tissue $)=(\mathrm{A}-\mathrm{V} / \mathrm{A}) \times \mathrm{A} \times$ 
plasma flow. Although the coronary sinus of the newborn receives small amounts of blood flow from the left atrium and right ventricular free wall, approximately $85 \%$ of coronary sinus flow comes from the left ventricular free wall and septum (18). Blood flows to the left ventricular free wall and septum are similar in newborn lambs (18).

An approximation of $\mathrm{LV}$ secretion of NE into blood was made based on two assumptions: 1 ) cardiac production of $\mathrm{E}$ is negligible, and 2) uptake of E and NE by LV tissue is approximately the same $(19,20)$. Therefore 1$)$ the net LV uptake of $E$ should equal the total LV uptake of $\mathrm{E}, 2$ ) the fractional extraction of $\mathrm{E}$ is a measure of the true fractional extraction of NE (i.e. if $\mathrm{LV}$ NE secretion were zero), and 3) total NE uptake from blood can be estimated by $(\mathrm{A}-\mathrm{V} / \mathrm{A})_{\mathrm{E}} \times \mathrm{A}_{\mathrm{NE}} \mathrm{x}$ flow. Then: estimated $\mathrm{LV} \mathrm{NE}$ secretion $=($ estimated total NE uptake - net NE uptake $)=[(\mathrm{A}$ $\left.\mathrm{V} / \mathrm{A})_{\mathrm{E}}-(\mathrm{A}-\mathrm{V} / \mathrm{A})_{\mathrm{NE}}\right] \times \mathrm{A}_{\mathrm{NE}} \times$ flow.

Experimental protocols. Group 1. Fifteen lambs were used to determine the effects of a change in ductus arteriosus patency on LV performance and catecholamine secretion. Seven lambs had their ductus kept open after delivery; eight lambs had their ductus closed mechanically (by closing the snare) $30 \mathrm{~min}$ after delivery. The lambs were allowed to stabilize for at least $3 \mathrm{~h}$ after delivery. After this time, there were no further changes in $\mathrm{FiO}_{2}$ or ventilator pressure settings. The animals were studied between 4 and $6 \mathrm{~h}$ after delivery. The effects of a change in ductus patency were examined by making measurements (heart rate, blood pressures, peak $\mathrm{dP} / \mathrm{dt}$, microsphere blood flows, arterial blood gases, $\mathrm{pH}$, hematocrit, and plasma catecholamines) $15 \mathrm{~min}$ before and 35 min after a change in ductus arteriosus patency (i.e. tightening the snare in a lamb whose ductus previously had been patent or loosening the snare in a lamb whose ductus had been closed). Ventilator settings and arterial blood gases at the time of measurements with closed ductus were: $\mathrm{FiO}_{2}=0.67 \pm 0.24$, peak inspiratory pressure $=23 \pm 1 \mathrm{~cm} \mathrm{H}_{2} \mathrm{O}, \mathrm{pH} 7.42 \pm 0.13, \mathrm{PaO}_{2}=$ $134 \pm 58$ torr, and $\mathrm{PaCO}_{2}=34 \pm 13$ torr. Settings and blood gases at the time of measurements with open ductus were: $\mathrm{FiO}_{2}$ $=0.67 \pm 0.24$, peak inspiratory pressure $=23 \pm 1 \mathrm{~cm} \mathrm{H}{ }_{2} \mathrm{O}, \mathrm{pH}$ $=7.43 \pm 0.06, \mathrm{PaO}_{2}=225 \pm 63$ torr, and $\mathrm{PaCO}_{2}=28 \pm 8$ torr.

In six of the lambs, after the above measurements were made, the ductus was closed, and an intravenous infusion of warmed $\left(39^{\circ} \mathrm{C}\right) 0.9 \mathrm{~g} / 100 \mathrm{ml} \mathrm{NaCl}$ was begun into the superior vena cava to study the effects of changes in LV end-diastolic pressure on peak $\mathrm{dP} / \mathrm{dt}$.

Group 2. Twenty-four lambs were used to examine the role of $\beta$-adrenergic stimulation in maintaining cardiac output during baseline conditions and during a volume load. All lambs had their ductus closed by $30 \mathrm{~min}$ after delivery and were allowed to stabilize for an additional $3 \mathrm{~h}$. After this time, there were no further changes in $\mathrm{FiO}_{2}$ or ventilator pressure settings. Heart rate was controlled by pacing the left atrium at a rate 5 beats $/ \mathrm{min}$ faster than the spontaneous heart rate (model $\mathrm{S} 4 \mathrm{G}$ stimulator, Grass Instruments, Quincy, MA).

In nine lambs, $30 \mathrm{~min}$ after baseline measurements, $50 \mathrm{ml} / \mathrm{kg}$ of warmed $\left(39^{\circ} \mathrm{C}\right) 0.9 / 100 \mathrm{ml} \mathrm{NaCl}$ was infused into the superior vena cava over a 3-min period. This volume and rate of infusion were chosen because they produced stable LV end-diastolic pressure elevations between 18 and 25 torr. In preliminary studies, we found that this range of LV end-diastolic pressures caused a maximal increase in stroke volume and peak $\mathrm{dP} / \mathrm{dt}$ in three preterm lambs that had precalibrated electromagnetic flow transducers applied around the ascending aorta (above the coronary arteries) in addition to the surgical preparation described above (Fig. 1). This is also the optimal range for full-term newborn lambs $(11,12)$. LV end-diastolic pressure reached its maximum value by $1.5 \mathrm{~min}$ after the start of the infusion and remained stable over the next $1.5 \mathrm{~min}$. Microsphere measurements were made after $1.5 \mathrm{~min}$ of infusion when the $\mathrm{LV}$ enddiastolic pressure had plateaued.

The 15 other lambs were pretreated with $1 \mathrm{mg} / \mathrm{kg}$ propranolol hydrochloride (Inderal, Ayerst Lab., New York, NY) intravenous
$10 \mathrm{~min}$ before the baseline measurement and $10 \mathrm{~min}$ before the volume load.

Statistics. We compared measurements by a paired $t$ test or unpaired t-test where appropriate. The level of significance was $p<0.05$ (two-tailed). The data are reported as means $\pm \mathrm{SD}$.

\section{RESULTS}

Group 1. Table 1 examines the effects of a change in ductus arteriosus patency on LV performance. In all 15 lambs, the left to right shunt through the ductus was more than $40 \%$ of the LV output; the mean shunt when the ductus was open was $58 \pm$ $12 \%$. When the ductus was open, there was no change in heart rate. As a result, the increase in LV output was due entirely to an increase in stroke volume. The increase in stroke volume was associated with an increase in LV end-diastolic pressure, a decrease in total resistance, as well as an increase in peak $\mathrm{dP} / \mathrm{dt}$.

To see whether the increase in peak $\mathrm{dP} / \mathrm{dt}$ was due to the increase in LV end-diastolic filling pressure, the following experimental protocol was used in six lambs (Table 2). First, measurements were made when the ductus was open and closed. Then the lamb's ductus was closed, and an intravenous infusion was begun. We continuously recorded measurements of peak $\mathrm{dP} / \mathrm{dt}$ and LV end-diastolic pressure during the infusion; then we compared the value of peak $\mathrm{dP} / \mathrm{dt}$ recorded during the infusion at the LV end-diastolic pressure that corresponded to the value of the LV end-diastolic pressure recorded when the ductus was open (during the preinfusion period). When the ductus was open, there was an increase in LV end-diastolic pressure from 5.5 to

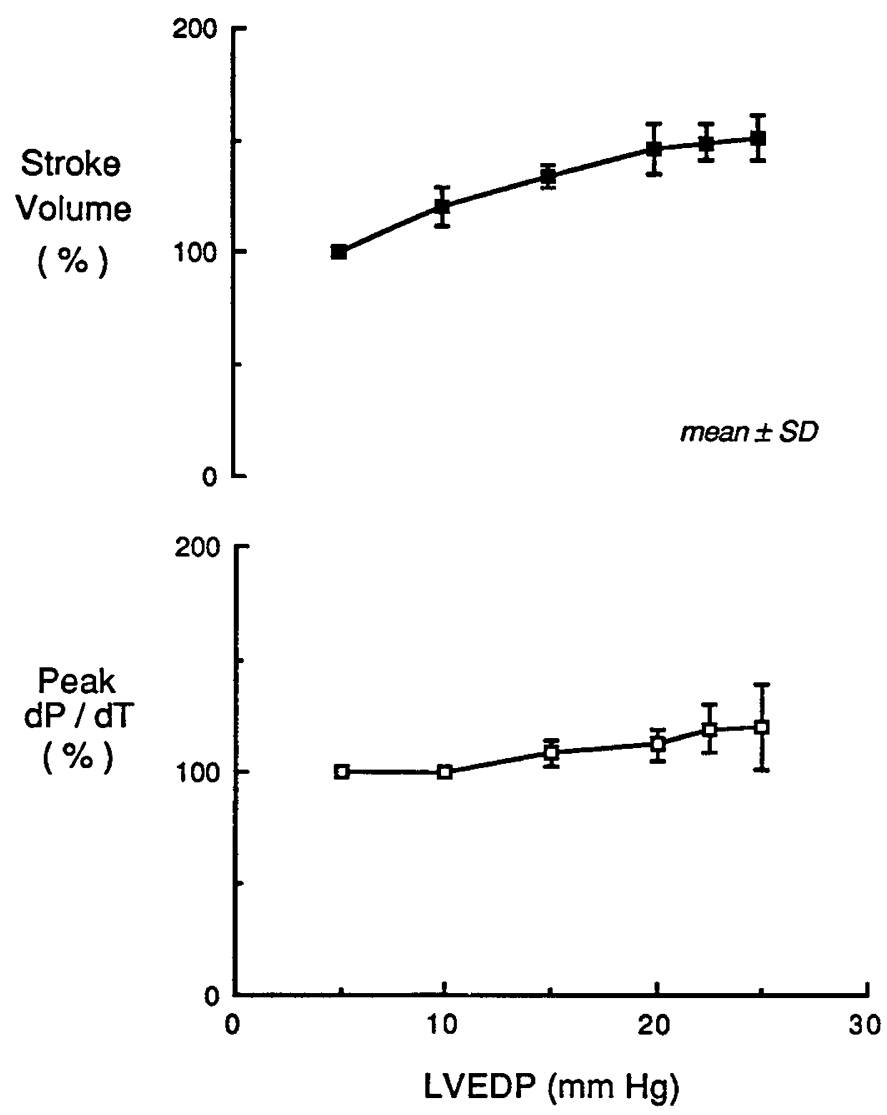

Fig. 1. Effect of a saline infusion on stroke volume and peak $\mathrm{dP} / \mathrm{dt}$ in three preterm lambs. Three premature fetal lambs were prepared as described in "Methods." They were delivered 1 day later and studied between 4 and $6 \mathrm{~h}$ after delivery. $\mathrm{NaCl} 0.9 \mathrm{~g} / 100 \mathrm{ml}$ was infused into the superior vena cava at $50 \mathrm{ml} / \mathrm{kg}$ during a $3-\mathrm{min}$ period. Continuous measurements of cardiac output, heart rate, and peak $\mathrm{dP} / \mathrm{dt}$ were recorded. Values of stroke volume and peak $\mathrm{dP} / \mathrm{dt}$ are expressed as a percent of preinfusion values. Values represent mean $\pm \mathrm{SD}$. 
PDA: CATECHOLAMINES AND CONTRACTILE STATE

Table 1. Cardiac performance in preterm lambs with and without $P D A(n=15, \pm S D)^{*}$

\begin{tabular}{|c|c|c|c|c|c|c|}
\hline & $\begin{array}{c}\mathrm{LVO} \\
\mathrm{ml} / \mathrm{min} \text {. } \\
\mathrm{kg}^{-1}\end{array}$ & $\begin{array}{c}\text { HR } \\
\text { beats } / \mathrm{min}\end{array}$ & $\begin{array}{c}\mathrm{SV} \\
\mathrm{ml} / \mathrm{kg}\end{array}$ & $\begin{array}{l}\text { LVEDP } \\
\mathrm{mm} \mathrm{Hg}\end{array}$ & $\begin{array}{c}\text { R total } \\
\mathrm{mm} \mathrm{Hg} / \mathrm{ml} \cdot \mathrm{min}^{-1} \cdot \mathrm{kg}^{-1}\end{array}$ & $\begin{array}{c}\text { Peak dP/dt } \\
\mathrm{mm} \mathrm{Hg} / \mathrm{s}\end{array}$ \\
\hline \multirow[t]{2}{*}{ Ductus closed } & 136 & 170 & 0.81 & 3.8 & 0.499 & 1805 \\
\hline & \pm 56 & \pm 18 & \pm 0.32 & \pm 2.9 & \pm 0.215 & \pm 558 \\
\hline \multirow[t]{2}{*}{ Ductus open* } & 261 & 175 & 1.50 & 7.3 & 0.145 & 2184 \\
\hline & \pm 103 & \pm 22 & \pm 0.62 & \pm 3.7 & \pm 0.061 & \pm 605 \\
\hline$p$ & $10^{-4}$ & NS & $10^{-4}$ & $10^{-4}$ & $10^{-4}$ & $10^{-2}$ \\
\hline
\end{tabular}

* LVO, left ventricular output; HR, heart rate; SV, stroke volume.

Table 2. Effect of an increase in left ventricular end diastolic pressure on peak $d P / d t$ : saline infusion versus open ductus $(n=6, \pm S D)$

\begin{tabular}{lcccc}
\hline & \multicolumn{2}{c}{ PDA } & \multicolumn{2}{c}{ Volume load } \\
\cline { 2 - 3 } \cline { 5 - 6 } & Closed & Open* & Closed & $\begin{array}{c}\text { Closed } \\
\text { + volume }\end{array}$ \\
\hline Heart rate & 174 & 174 & 181 & 184 \\
(beats/min) & \pm 27 & \pm 27 & \pm 26 & \pm 24 \\
LVEDP & 5.5 & 9.7 & 5.5 & 9.7 \\
(mm Hg) & \pm 3.2 & \pm 4.4 & \pm 3.2 & \pm 4.4 \\
Peak dP/dt & 1746 & 2360 & 1917 & 1986 \\
(mm Hg/s) & \pm 457 & \pm 605 & \pm 399 & \pm 395 \\
\hline
\end{tabular}

${ }^{*}$ Left to right shunt when ductus is open $=62 \pm 6 \%$ of left ventricular output.

$9.7 \mathrm{~mm} \mathrm{Hg}(p<0.02)$ and an increase in peak $\mathrm{dP} / \mathrm{dt}(1746$ to $2360 \mathrm{~mm} \mathrm{Hg} / \mathrm{s}, p<0.05)$. When the LV end-diastolic pressure was increased by the infusion from 5.5 to $9.7 \mathrm{~mm} \mathrm{Hg}$, there was no significant change in peak dP/dt (1917 to $1986 \mathrm{~mm} \mathrm{Hg} / \mathrm{s}$ ). For the same increase in LV end-diastolic pressure, peak $\mathrm{dP} / \mathrm{dt}$ was significantly greater when the ductus was open compared with the infusion when the ductus was closed (2360 versus 1986 $\mathrm{mm} \mathrm{Hg} / \mathrm{s}, p<0.01$ ). Therefore, the increase in peak $\mathrm{dP} / \mathrm{dt}$ that occurred when the ductus was open probably was not due to the associated increase in LV end-diastolic pressure.

Table 3 summarizes the effects of a change in ductus arteriosus patency on NE and E concentrations. Measurements were made during 14 changes in ductus patency in seven premature lambs. When the ductus was open, there were no changes in circulating arterial E or NE concentrations. There was a significant increase in plasma flow to the LV free wall. Using the arterial and venous concentration differences and the equations described above, we calculated estimated myocardial secretion rates of NE. Estimated LV NE secretion into the blood increased by $63 \%$ when the ductus was open.

Group 2. To evaluate the effects of $\beta$-adrenergic stimulation on LV output and contractility, propranolol $(1 \mathrm{mg} / \mathrm{kg})$ was given to 15 preterm lambs whose ductus were closed. Propranolol decreased the spontaneous heart rate from $150 \pm 14$ to $118 \pm 11$ beats $/ \min (p<0.0001)$. Therefore, to study the effects of propranolol on contractility, the left atria of the lambs were paced at a rate slightly above their spontaneous heart rate (Table 4). Despite no change in paced heart rate, propranolol caused a significant reduction in peak $\mathrm{dP} / \mathrm{dt}$ as well as a decrease in $\mathrm{LV}$ output and in stroke volume. There were no changes in LV enddiastolic pressure or in systemic vascular resistance. After propranolol, there was a significant increase in pulmonary vascular resistance from $0.17 \pm 0.07$ to $0.23 \pm 0.13$ torr $/ \mathrm{ml} \cdot \mathrm{kg}^{-1} \cdot \mathrm{min}^{-1}$ $(p<0.01)$. Propranolol had no effects on $\mathrm{pH}, \mathrm{PaO}_{2}$, or $\mathrm{PaCO}_{2}$.

In Table 5, the effects of propranolol are examined in premature lambs during a saline volume load. Both groups of lambs had their ductus closed, and both had their heart rates controlled by left atrial pacing. In the control group, the volume infusion produced a significant increase in stroke volume $(p<0.001)$, which was associated with an increase in peak dP/dt $(p<0.005)$,
Table 3. Effect of opening the ductus arteriosus on stroke volume, peak $d P / d t$, plasma catecholamines, and left ventricular NE secretion $(n=14, \pm S D)^{*}$

\begin{tabular}{|c|c|c|c|}
\hline & Ductus closed & Ductus open $\dagger$ & $p$ \\
\hline $\begin{array}{l}\text { SV } \\
(\mathrm{ml} / \mathrm{kg})\end{array}$ & $\begin{array}{r}0.87 \\
\pm 0.26\end{array}$ & $\begin{array}{r}1.64 \\
\pm 0.53\end{array}$ & $10^{-3}$ \\
\hline $\begin{array}{l}\text { Peak dP } / \mathrm{dt} \\
(\mathrm{mm} \mathrm{Hg} / \mathrm{s})\end{array}$ & $\begin{array}{r}1735 \\
\pm 593\end{array}$ & $\begin{array}{r}2025 \\
\pm 754\end{array}$ & $10^{-2}$ \\
\hline $\begin{array}{l}\text { Epi-art } \\
(\mathrm{pg} / \mathrm{ml})\end{array}$ & $\begin{array}{r}235 \\
\pm 144\end{array}$ & $\begin{array}{r}300 \\
\pm 260\end{array}$ & NS \\
\hline $\begin{array}{l}\text { Epi-cs } \\
(\mathrm{pg} / \mathrm{ml})\end{array}$ & $\begin{array}{r}97 \\
\pm 62\end{array}$ & $\begin{array}{r}101 \\
\pm 111\end{array}$ & NS \\
\hline $\begin{array}{l}\text { Nepi-art } \\
(\mathrm{pg} / \mathrm{ml})\end{array}$ & $\begin{array}{r}564 \\
\pm 353\end{array}$ & $\begin{array}{r}569 \\
\pm 365\end{array}$ & NS \\
\hline $\begin{array}{l}\text { Nepi-cs } \\
(\mathrm{pg} / \mathrm{ml})\end{array}$ & $\begin{array}{r}383 \\
\pm 215\end{array}$ & $\begin{array}{r}469 \\
\pm 314\end{array}$ & NS \\
\hline $\begin{array}{l}\text { Q plasma } \\
(\mathrm{ml} / \mathrm{min} \cdot \mathrm{g} \mathrm{LV}\end{array}$ & $\begin{array}{r}81 \\
\pm 41\end{array}$ & $\begin{array}{r}98 \\
\pm 39\end{array}$ & $5 \times 10^{-2}$ \\
\hline $\begin{array}{l}\text { Nepi secretion } \\
\left(\mathrm{pg} / \mathrm{min} \cdot \mathrm{g} \mathrm{LV} \mathrm{V}^{-1}\right)\end{array}$ & $\begin{array}{r}114 \\
\pm 88\end{array}$ & $\begin{array}{r}186 \\
\pm 98\end{array}$ & $10^{-2}$ \\
\hline
\end{tabular}

* Epi-art and Epi-cs, plasma $\mathrm{E}$ concentrations in ascending aorta and coronary sinus; Nepi-art and Nepi-cs, plasma norepinephrine concentrations in ascending aorta and coronary sinus; $\dot{Q}$ plasma, plasma flow rate to LV free wall; Nepi secretion, estimated Nepi secretion; SV, stroke volume.

$\dagger$ Left to right shunt when the ductus is open $=54 \pm 15 \%$ of left ventricular output.

Table 4. Effect of propranolol $(1 \mathrm{mg} / \mathrm{kg}$ ) on spontaneous heart rate, peak $d P / d t$, and stroke volume in lambs with closed ductus $(n=15, \pm S D)$

\begin{tabular}{|c|c|c|c|}
\hline & Ductus closed & $\begin{array}{l}\text { Ductus closed } \\
+ \text { propranolol }\end{array}$ & $p$ \\
\hline $\begin{array}{l}\text { Spontaneous heart rate } \\
\text { (beats/min) }\end{array}$ & $\begin{array}{r}150 \\
\pm 14\end{array}$ & $\begin{array}{r}118 \\
\pm 11\end{array}$ & $10^{-4}$ \\
\hline $\begin{array}{l}\text { Paced heart rate* } \\
\text { (beats/min) }\end{array}$ & $\begin{array}{r}159 \\
\pm 22\end{array}$ & $\begin{array}{r}155 \\
\pm 24\end{array}$ & NS \\
\hline $\begin{array}{l}\mathrm{SV}^{*} \\
(\mathrm{ml} / \mathrm{kg})\end{array}$ & $\begin{array}{r}0.98 \\
\pm 0.29\end{array}$ & $\begin{array}{r}0.82 \\
\pm 0.26\end{array}$ & $10^{-2}$ \\
\hline $\begin{array}{l}\text { Peak dP/dt* } \\
(\mathrm{mm} \mathrm{Hg} / \mathrm{s})\end{array}$ & $\begin{array}{r}2106 \\
\pm 782\end{array}$ & $\begin{array}{r}1443 \\
\pm 493\end{array}$ & $10^{-3}$ \\
\hline $\begin{array}{l}\text { LVEDP* } \\
\text { (mm Hg) }\end{array}$ & $\begin{array}{r}4.4 \\
\pm 2.2\end{array}$ & $\begin{array}{r}3.9 \\
\pm 2.7\end{array}$ & NS \\
\hline $\begin{array}{l}\text { R total } \\
\left(\mathrm{mm} \mathrm{Hg} / \mathrm{ml} \cdot \mathrm{min}^{-1} \cdot \mathrm{kg}^{-1}\right)\end{array}$ & $\begin{array}{r}0.35 \\
\pm 0.18\end{array}$ & $\begin{array}{r}0.37 \\
\pm 0.14\end{array}$ & NS \\
\hline
\end{tabular}

*Values obtained during left atrial pacing; $\mathrm{R}$ total $=$ systemic vascular resistance.

an increase in LV end-diastolic pressure $(p<0.0)$, and a decrease in systemic vascular resistance $(p<0.0001)$. Propranolol-treated lambs did not increase their peak $\mathrm{dP} / \mathrm{dt}$ to the same magnitude as did the control lambs. As a result, they had a significantly smaller stroke volume during the volume load despite having a similar increase in LV end-diastolic pressure and a similar de- 
Table 5. Effect of propranolol during saline infusion of $50 \mathrm{ml} / \mathrm{kg}$ over 3-min period in lambs with closed ductus $( \pm S D)^{*}$

\begin{tabular}{|c|c|c|c|c|}
\hline & \multicolumn{2}{|c|}{ Control $(n=9)$} & \multicolumn{2}{|c|}{$\begin{array}{c}\text { Propranolol } \\
(n=15)\end{array}$} \\
\hline & Closed & $\begin{array}{c}\text { Closed } \\
+ \text { volume } \\
\end{array}$ & Closed & $\begin{array}{c}\text { Closed } \\
+ \text { volume } \\
\end{array}$ \\
\hline Heart rate & 160 & 160 & 155 & 157 \\
\hline (beats/min) & \pm 24 & \pm 24 & \pm 24 & \pm 25 \\
\hline $\mathrm{SV} \dagger$ & 0.94 & 1.38 & 0.82 & $1.13^{a}$ \\
\hline$(\mathrm{ml} / \mathrm{kg})$ & \pm 0.24 & \pm 0.26 & \pm 0.26 & \pm 0.23 \\
\hline Peak dp/dt $\dagger$ & 1985 & 2699 & 1443 & $1600^{b}$ \\
\hline$(\mathrm{mm} \mathrm{Hg} / \mathrm{s})$ & \pm 342 & \pm 560 & \pm 493 & \pm 464 \\
\hline LVEDP $\dagger$ & 4.3 & 21.9 & 3.9 & 20.6 \\
\hline$(\mathrm{mm} \mathrm{Hg}) \mathrm{R}$ total $\dagger$ & \pm 2.4 & \pm 2.3 & \pm 2.7 & \pm 3.5 \\
\hline \multirow[t]{2}{*}{$\left(\mathrm{mm} \mathrm{Hg} / \mathrm{ml} \cdot \min ^{-1} \cdot \mathrm{kg}^{-1}\right)$} & 0.40 & 0.29 & 0.37 & 0.29 \\
\hline & \pm 0.13 & \pm 0.10 & \pm 0.14 & \pm 0.13 \\
\hline
\end{tabular}

${ }^{*}$ Closed + volume versus closed + volume + propranolol. . ${ }^{a} p<$ $0.05 ;{ }^{b} p<0.002$.

$\dagger$ LA pacing.

crease in resistance as did the control lambs. Propranolol had no effects on the $\mathrm{pH}, \mathrm{PaO}_{2}$, or $\mathrm{PaCO}_{2}$ measured during the volume load.

\section{DISCUSSION}

We found that preterm lambs with moderate respiratory distress can double their LV output when challenged with a left to right shunt through the ductus arteriosus. This increase in LV output was due entirely to an increase in stroke volume. In preterm lambs with a PDA, this increase in LV performance was associated with an increase in preload (LVEDP), a decrease in $\mathrm{R}_{\mathrm{T}}$, and an increase in peak $\mathrm{dP} / \mathrm{dt}$ (Table 1 ).

Peak $\mathrm{dP} / \mathrm{dt}$ is an index of cardiac performance that is unaffected by afterload but is sensitive to changes in preload, heart rate, and myocardial contractility $(21-23)$. If there are no changes in preload or heart rate, then changes in peak $\mathrm{dP} / \mathrm{dt}$ reflect changes in contractility. During our studies, there were no changes in heart rate either during the saline volume load or during the change in ductus patency. We found that a large volume load that increases preload and LV end-diastolic pressure to greater than $15 \mathrm{~mm} \mathrm{Hg}$ can produce an increase in peak $\mathrm{dP} /$ dt (Fig. 1; Table 5). Possible causes of the increase in peak dP/ $\mathrm{dt}$ include increasing end-diastolic volume (which is independent of alterations in contractility) and volume induced augmentation of catecholamine release (which directly alters left ventricular contractility). (For a discussion of large preloads, see below.) However, we found that smaller increases in preload (in the range produced by opening the ductus arteriosus) produced a negligible change in peak $\mathrm{dP} / \mathrm{dt}$ (Table 2). There are several assumptions that are involved with this conclusion. We have not used a direct index of preload (such as end-diastolic volume) in our studies. Instead, we have used the indirect index, LVEDP. For the LVEDP to reflect accurately the changes in preload produced by opening a ductus shunt or during a saline infusion, the compliance of the left ventricle must be the same in the two conditions. Similar studies by other investigators would support our conclusion. Baylen et al. (24) produced volume infusions with whole blood (instead of saline) in preterm and full-term lambs. Despite increases in LVEDP that were more $(11-13 \mathrm{~mm}$ $\mathrm{Hg}$ ) than those produced in our study and despite increases in left ventricular end-diastolic volume of 25 to $50 \%$, they observed no increase in peak $\mathrm{dP} / \mathrm{dt}$ during their volume infusions (24). Similarly, Quinones et al. (22) found that peak dP/dt could be used to evaluate acute changes in contractility since its response to volume loading (within the physiologic range of blood pressures) was small. Therefore, the significant increase in peak $\mathrm{dP} /$ dt that we observed when the ductus was opened most likely represented an increase in LV contractility.

In addition, the increase in peak $\mathrm{dP} / \mathrm{dt}$ that was seen after the ductus arteriosus was opened was consistent with the simultaneous increase in estimated LV NE secretion. During this study, we saw no change in circulating concentrations of $E$ or NE. To estimate the release of NE from the heart, we have assumed that there is negligible cardiac release of $E$ and that the uptake of $E$ and NE is approximately equal. The former assumption is supported by studies showing that cardiac $\mathrm{E}$ content is only $5 \%$ of $\mathrm{NE}$ content (25) and that plasma $\mathrm{E}$ is not measurable in adrenalectomized people during stress (26). The second assumption is based on in vitro studies that examine uptake of labeled catecholamines by cardiac muscle (27) and on in vivo studies during a large increase in arterial NE concentrations (28). Furthermore, because only a relatively small percentage of neuronally released NE normally enters the blood (29), our calculation of cardiac NE secretion into the blood is an underestimate of total release of NE from cardiac sympathetic neurons.

As shown in Table 3, estimated cardiac NE secretion into blood increased by $63 \%$ when the ductus was opened, suggesting that the sympathetic nerves to the heart participated in adrenergic activation of the LV. This would explain the increase in peak $\mathrm{dP} / \mathrm{dt}$ when the ductus was opened. Our findings extend those made in adult animals during an acutely opened arteriovenous fistula; in those studies, the increase in stroke volume after opening of the fistula was accompanied by increased plasma catecholamines and contractility $(1-3)$.

Herein, no changes in circulating NE or E were seen when the ductus was open. Myocardial secretion of NE, however, was increased. These results highlight the importance of evaluating specific regional kinetics of secretion and clearance of norepinephrine in specific pathophysiologic states as suggested by Esler and coworkers $(30,31)$.

While our results demonstrated increased LV NE secretion with the ductus open, there was still a net clearance of NE across the heart. Net myocardial secretion of NE has been demonstrated in response to stimulation of cardiac adrenergic nerves $(32,33)$ and exercise (34). This suggests that the relative contribution of myocardial NE release to changes in the concentration of circulating NE is highly dependent on species, stimulus, and developmental age.

It is interesting to note that we did not see a change in heart rate when the ductus was opened, despite the increase in cardiac $\mathrm{NE}$ secretion and the increase in peak $\mathrm{dP} / \mathrm{dt}$. Perhaps differences in regional distribution of myocardial $\beta$-receptors or differences in density of innervation might explain why an inotropic effect was seen without an increase in heart rate.

We used the $\beta$-adrenoreceptor blocker propranolol to evaluate the importance of $\beta$-adrenergic stimulation in the preterm newborn. $\beta$-Adrenergic blockade produced a significant decrease in heart rate, peak $\mathrm{dP} / \mathrm{dt}$, and stroke volume in lambs with a closed ductus (Table 4). Thus the high circulating catecholamine concentrations observed after delivery in preterm lambs may play an important role in maintaining heart rate and cardiac output $(7,8)$.

Propranolol produced a significant increase in pulmonary vascular resistance and a decrease in the ratio of systemic vascular resistance to pulmonary vascular resistance. As a result, after propranolol, there was a significant decrease in left to right shunt through the same size open ductus arteriosus (data not shown). Because propranolol altered the amount of left to right shunt through an open ductus, it was not possible to use the same animal to compare the effects of propranolol (before and after treatment) on LV output and contractility. However, when propranolol was given to 12 lambs (data not shown) whose heart rates were controlled by left atrial pacing, there was no longer a significant increase in $\mathrm{dP} / \mathrm{dt}$ when the ductus was open (closed: $1289 \pm 336 \mathrm{~mm} \mathrm{Hg} / \mathrm{s}$; open: $1408 \pm 500 \mathrm{~mm} \mathrm{Hg} / \mathrm{s}$ ). In these lambs, the mean left to right shunt was $41 \pm 19 \%$ of the LV 
output. Therefore, in an attempt to evaluate the role of $\beta$ adrenergic stimulation in preterm animals during a volume load, we used saline infusions in animals with closed ductus that were undergoing left atrial pacing. It should be pointed out that volume loading of the left ventricle by opening the ductus may not be directly comparable to saline infusion (with both right ventricle and LV loading) in lambs undergoing left atrial pacing (with possible left to right foramen ovale shunting). With that caveat in mind, we found that saline infusions that elevated LV end diastolic pressure to $18-25 \mathrm{~mm} \mathrm{Hg}$, in lambs with closed ductus, produced significant increases in peak $\mathrm{dP} / \mathrm{dt}$ and stroke volume. When challenged with a volume load, propranololtreated lambs did not increase their peak $\mathrm{dP} / \mathrm{dt}$ and stroke volume to the same magnitude as did control lambs. These findings are consistent with the hypothesis that part of the increased cardiac performance observed during a large volume load is mediated by $\beta$-adrenergic stimulation.

Studies performed in fetal lambs (35-37) have recorded measurements of LV contractility comparable to those obtained in adult sheep. However, the fetus has a limited capacity to increase its stroke volume above resting values when challenged either with a volume load $(38,39)$ or with $\beta$-adrenergic stimulation $(40$, 41).

On the other hand, studies performed in full-term newborn lambs have found that measurements of LV contractility and output in the newborn far exceeded those in the adult (9-13). The high levels of LV contractility and performance in the fullterm newborn have been attributed to the predominance of sympathetic autonomic neural stimulation in these animals (7, 14). Although somewhat better than the fetus, the full-term newborn lamb's ability to increase its LV contractility and stroke volume above resting values when challenged either with a volume load (11-14), or with $\beta$-adrenergic stimulation $(11,14)$ is also limited. The full-term newborn may be unable to improve ventricular performance substantially, because it may already be functioning at maximal contractility due to high resting state demand.

We found that, when the ductus was closed, the LV contractility and output in preterm lambs studied 4 to $6 \mathrm{~h}$ after delivery were less than those previously reported for full-term lambs. This was despite the higher circulating concentrations of catecholamines found early after birth in premature animals (8). In addition, the preterm lamb appeared to be able to increase its contractility and stroke volume through enhanced sympathetic neural stimulation.

Our observations differ from those reported by Baylen and coworkers $(24,42,43)$, who studied premature (120-124 days gestation) lambs during the first $2 \mathrm{~h}$ after delivery. They found that the contractility, as described by either the peak $\mathrm{dP} / \mathrm{dt}$ or the peak $\mathrm{dP} / \mathrm{dt}$ normalized to end-diastolic volume, remained essentially unchanged when there was a change in ductus patency (43) or an increase in volume load (24). In addition, propranolol seemed to have no effect on resting state values of contractility (42). Our studies differ both in the gestational age of the lambs used and in the time after delivery when they were studied. In premature lambs, there is a marked increase in the secretion of catecholamines that occurs immediately after birth; this increase peaks by $2 \mathrm{~h}$, drops to $25 \%$ of this peak by $4 \mathrm{~h}$, and continues to decline thereafter (8). We would hypothesize that the inability of Baylen et al. (42) to demonstrate an increase in $\beta$-adrenergic stimulation of myocardial contractility is due to the timing of their studies; specifically, animals studied within the first $2 \mathrm{~h}$ after delivery may be under maximal $\beta$-adrenergic stimulation and may not have any reserve for additional catecholamine secretion. The question also remains whether the doses of propranolol used in their studies could effectively block the markedly elevated sympathetic neural stimulation (42).

We would hypothesize that, after the initial catecholamine "surge" at delivery, $\beta$-adrenergic tone plays a significant role in increasing contractile state and left ventricular performance in preterm lambs. Preterm lambs faced with a volume load have a significant increase in myocardial NE secretion and an increase in myocardial contractility. This increase in contractility, together with the increase in preload and decrease in afterload, enables the premature lamb to increase its stroke volume when there is a change in ductus arteriosus patency.

Acknowledgments. The authors thank Mr. Carl McWatters and Mr. Bruce Payne for their help with the microsphere data analysis, Mr. Paul Sagan for his skill in preparing and editing this manuscript, and Drs. A. M. Rudolph and M. A. Heymann for their encouragement during this project.

\section{REFERENCES}

1. Fujisawa A, Sasayama S, Takahashi M, Nakamura M, Ohyagi A, Lee J, Yui Y, Kawai C 1984 Enhancement of left ventricular contractility after opening of an arteriovenous fistula in dogs. Cardiovasc Res 18:51-59

2. Nakano J, deSchryver C 1964 Effects of arteriovenous fistula on systemic and pulmonary circulations. Am J Physiol 207:1319-1324

3. Nakano J, Zekert H, Griege CW, Wang KM, Schaefer HS, Wégria R 1961 Effect of ventricular tachycardia and arteriovenous fistula on catecholamines blood level. Am J Physiol 200:413-416

4. Clyman RI, Mauray F, Heymann MA, Roman C 1987 Cardiovascular effects of a patent ductus arteriosus in preterm lambs with respiratory distress. $\mathbf{J}$ Pediatr 111:579-587

5. Clyman RI, Heymann MA, Mauray F 1987 How a patent ductus arteriosus effects the premature lamb's ability to handle additional volume loads. Pediatr Res 22:531-535

6. Lebowitz EA, Novick JS, Rudolph AM 1972 Development of myocardial sympathetic innervation in the fetal lamb. Pediatr Res 6:887-893

7. Padbury JF, Diakomanolis ES, Hobel CJ, Perelman A, Fisher DA 1981 Neonatal adaptation: sympatho-adrenal response to umbilical cord cutting. Pediatr Res 15:1483-1487

8. Padbury JF, Polk DH, Newnham JP, Lam RW 1985 Neonatal adaptation: greater sympathoadrenal response in preterm than full term fetal sheep at birth. Am J Physiol 248:E443-E449

9. Berman W Jr, Musselman J 1979 Myocardial performance in the newborn lamb. Am J Physiol 237:H66-H70

10. Cross KW, Dawes GS, Mott JC 1959 Anoxia, oxygen consumption and cardiac output in newborn lambs and adult sheep. J Physiol 146:316-343

11. Klopfenstein HS, Rudolph AM 1978 Postnatal changes in the circulation and responses to volume loading in sheep. Circ Res 42:839-845

12. Riemenschneider TA, Allen HD, Mason DT 1986 Maturational changes in myocardial pump performance in newborn lambs. Am Heart J 111:731736

13. Romero TE, Friedman WF 1979 Limited left ventricular response to a volume overload in the neonatal period: a comparative study with the adult animal. Pediatr Res 13:910-915

14. Teitel DF, Sidi D, Chin T, Brett C, Heymann MA, Rudolph AM 1985 Developmental changes in myocardial contractile reserve in the lamb. Pediatr Res 19:948-955

15. Fisher DJ, Heymann MA, Rudolph AM 1981 Myocardial consumption of oxygen and carbohydrates in newborn sheep. Pediatr Res 15:843-846

16. Durand DJ, Clyman RI, Heymann MA, Clements JA, Mauray F, Kitterman JA, Ballard P 1985 Effects of a protein free, synthetic surfactant on the survival and pulmonary function of preterm lambs. J Pediatr 107:775-780

17. Passon PG, Peuler JD 1973 A simplified radiometric assay for plasma norepinephrine and epinephrine. Anal Biochem 51:618-631

18. Fisher DJ, Heymann MA, Rudolph AM 1980 Myocardial oxygen and carbohydrate consumption in fetal lambs in utero and in adult sheep. Am J Physiol 238:H399-H405

19. Halter JB, Kelley KO, Gould KL 1982 Cardiac uptake and secretion of catecholamines during adrenergic stimulation in vivo. Am $\mathbf{J}$ Physiol 243:E52-E58

20. Woodman OL, Amano J, Hintze TH, Vatner SF 1986 Augmented catecholamine uptake by the heart during hemorrhage in the conscious dog. Am J Physiol 250:H76-H81

21. Fisher DJ, Gross DM 1983 The effect of atrial pacing induced tachycardia on left ventricular contractile function in conscious newborn and adult sheep. Pediatr Res 17:651-656

22. Quinones MA, Gaasch WH, Alexander JK 1976 Influence of acute changes in preload, afterload, contractile state and heart rate on ejection and isovolumic indices of myocardial contractility in man. Circulation 53:293-302

23. Van den Bos CG, Elzinga G, Westerhof N, Noble NIM 1973 Problems in the use of indices of myocardial contractility. Cardiovasc Res 7:834-848

24. Baylen BG, Ogata H, Ikegami M, Jacobs H, Jobe A, Emmanouilides GC 1986 Left ventricular performance and contractility before and after volume infusion: a comparative study of preterm and full-term newborn lambs. Circulation 73:1042-1049

25. Neubauer B, Christensen NJ 1975 Norepinephrine, epinephrine, and dopamine contents of the cardiovascular system in long term diabetics. Diabetes 25:610

26. Gerich J, Davis J, Lorenzi M, Rizza R, Bohannon N, Karam J, Lewis S, 
Kaplan R, Schultz R, Cryer P 1979 Mechanisms of recovery from hypoglycemia in man. I. Interaction of glucagon and epinephrine. Am J Physiol 236:E380-E385

27. Iversen LI 1975 Uptake of circulating catecholamines into tissues. In: Handbook of Physiology, Endocrinology, Adrenal Gland, Vol. 6. American Physiological Society, Washington, DC, section 7, pp 713-722

28. Brown MJ, Jenner DA, Allison DJ, Dollery CT 1981 Variations in individual organ release of norepinephrine measured by an improved radioenzymatic technique: limitations of peripheral venous measurements in the assessment of sympathetic nervous activity. Clin Sci 65:585-590

29. Kopin IJ, Lake RC, Ziegler M 1978 Plasma levels of norepinephrine. Ann Intern Med 88:671-680

30. Esler M, Jennings G, Korner P, Blombery P, Sacharias N, Leonard P 1984 Measurement of total and organ specific norepinephrine kinetics in humans. Am J Physiol 247:E21-E28

31. Hasking GJ, Esler MD, Jennings GL, Burton D, Johns JA, Korner PI 1986 Norepinephrine spillover to plasma in patients with congestive heart failure: evidence of increased overall and cardiorenal sympathetic nervous activity. Circulation 73:615-621

32. Levy MN, Blattberg B 1977 Progressive reduction in norepinephrine overflow during cardiac sympathetic nerve stimulation in the anesthetized dog. Cardiovasc Res 11:481-488

33. Levy MN, Blattberg B 1977 Correlation of the mechanical responses of the heart with the norepinephrine overflow during cardiac synpathetic neural stimulation in the dog. Cardiovasc Res 11:481-488

34. Yamaguchi N, de Champlain J, Nadeau R 1975 Correlation between the response of the heart to sympathetic stimulation and the release of endoge- nous catecholamines into the coronary sinus of the dog. Circ Res 36:662668

35. Berman W $J_{r}$, Ravenscroft PJ, Sheiner LB, Heymann MA, Melmon KI, Rudolph AM 1977 Differential effects of digoxin at comparable concentrations in tissues of detal and adult sheep. Circ Res 41:635-642

36. Kirkpatrick SE, Covell JW, Friedman W 1973 A new technique for the continuous assessment of fetal and neonatal cardiac performance. Am J Obstet Gynecol 116:963-972

37. Kirkpatrick SE, Pitlick PT, Maliboff J, Friedman WF 1976 Frank Starling relationship as an important determinant of fetal cardiac output. Am J Physiol 231:495-500

38. Gilbert RD 1980 Control of fetal cardiac output during changes in blood volume. Am J Physiol 238:H80-H86

39. Thornburg KL, Morton MJ 1983 Filling and arterial pressures as determinants of RV stroke volume in the sheep fetus. Am J Physiol 244:H656-H663

40. Gilbert RD 1982 Effects of afterload and baroreceptors on cardiac function in fetal sheep. J Dev Physiol 4:299-309

41. Picardo S, Li C, Tyndall M, Rudolph AM 1986 Fetal cardiovascular response to beta adrenoreceptor stimulation. Pediatr Res 20:371(abstr)

42.Baylen BG, Agata Y, Berry D, El Kady T, Ikegami M, Jobe A, Emmanouilides GC 1986 Left ventricular performance and contractility during beta adrenoreceptor blockade in the preterm newborn lamb. Clin Res 34:140(abstr)

43. Baylen BG, Ogata H, Oguchi K, Ikegami M, Jacobs H, Jobe A, Emmanouilides GC 1985 The contractility and performance of the preterm left ventricle before and after early patent ductus arteriosus occlusion in surfactant treated lambs. Pediatr Res 19:1053-1058 